J. Raptor Res. 43(4):377-381

(C) 2009 The Raptor Research Foundation, Inc.

\title{
Diet of the American Kestrel in Argentine Patagonia
}

\author{
Miguel Ángel Santillán, ${ }^{1}$ Alejandro Travaini, and Sonia Cristina Zapata
}

Centro de Investigaciones de Puerto Deseado, Universidad Nacional de la Patagonia Austral, CONICET, CC 238, Avenida Prefectura Naval S/N, 9050 Puerto Deseado, Santa Cruz, Argentina

Alejandro Rodríguez And José A. Donázar

Department of Conservation Biology, Estación Biológica de Doñana, Consejo Superior de Investigaciones Científicas, Américo Vespucio S/N, 41092 Sevilla, Spain

Diego Esteban Procopio and Juan Ignacio Zanón

Centro de Investigaciones de Puerto Deseado, Universidad Nacional de la Patagonia Austral, CONICET, CC 238, Avenida Prefectura Naval S/N, 9050 Puerto Deseado, Santa Cruz, Argentina

Key Words: American Kestrel; Falco sparverius; diet; Patagonia.

The American Kestrel (Falco sparverius) has a widespread distribution, from Alaska and Canada to Tierra del Fuego and the Falkland Islands, and occupies a variety of natural landscapes and human-modified habitats (Woods 1988, del Hoyo et al. 1994, Smallwood and Bird 2002). In Argentina, kestrels inhabit subtropical and semiarid forest, agroecosystems, the Andean Mountains, and scrubland steppes at sea level (Donázar et al. 1993, Travaini et al. 1995, Narosky and Yzurieta 2003). The species is abundant in valleys, plains, woodlands, and grassy hills (Donázar et al. 1993, Bellati 2000) but scarce in Argentina south of $47^{\circ}$ latitude (Travaini et al. 2004).

The American Kestrel is considered primarily insectivorous (Ferguson-Lees and Christie 2001, Smallwood and Bird 2002). In South America, the feeding ecology of this species has been studied in Chile (Greer and Bullock 1966, Yañez et al. 1980, Simonetti et al. 1982, Mella 2002, Figueroa and Corales 2004), Brazil (Cabral et al. 2006, Zillio 2006), and north-central Argentina (Beltzer 1990, Sarasola et al. 2003). In southern Argentina, kestrel breeding ecology (De Lucca 1992a, De Lucca 1993, De Lucca and Saggese 1993), hunting techniques (De Lucca 1992b), and pellet identification (Trejo and Ojeda 2002) have been described, but quantitative data on their food habits are lacking (Ferguson-Lees and Christie 2001, Bó et al. 2007). Here we present the first quantitative analysis of the diet of American Kestrels in Argentine Patagonia.

\footnotetext{
${ }^{1}$ Present address: Centro para el Estudio y Conservación de las Aves Rapaces en Argentina, Facultad de Ciencias Exactas y Naturales. Universidad Nacional de La Pampa. Avda. Uruguay 151, (6300) Santa Rosa, La Pampa, Argentina; email address: rapacero@yahoo.com.ar
}

\section{MeTHODS}

Study Area. We conducted our study in two provinces of Argentine Patagonia, Santa Cruz and Neuquén. There were three collection sites in Santa Cruz: Río Chico, Monumento Natural Bosques Petrificados, and Ría Deseado. Río Chico $\left(47^{\circ} 47^{\prime} \mathrm{S}, 65^{\circ} 49^{\prime} \mathrm{W}\right)$ is a river valley near the Andean foothills, with mean temperatures of $0-12{ }^{\circ} \mathrm{C}$ and annual precipitation of 300 $400 \mathrm{~mm}$. The predominant vegetation consists of shrubs (Chuquiraga aurea, Azorella caespitosa, Lycium repens and Nitrophila australis), some low trees (Schinus polygamus), and abundant tussock grasses (Distichlis sp.; Oliva et al. 2001, González and Rial 2004, Mazzoni and Vázquez 2004).

The Monumento Natural Bosques Petrificados $\left(47^{\circ} 66^{\prime} \mathrm{S}\right.$, $67^{\circ} 99^{\prime} \mathrm{W}$ ) is a protected area of $570 \mathrm{~km}^{2}$. The landscape is dominated by highland plateaus with rugged cliffs and valleys. Vegetation is composed primarily of tussock grasses and low, dome-shaped, spindly shrubs (Soriano 1983) with vegetative cover ranging from $<10 \%$ in the most arid regions up to $60 \%$ in valleys and lowlands (Ares et al. 1990, Bertiller and Bisigato 1998).

Ría Deseado is an estuarine natural reserve ca. $40 \mathrm{~km}$ long and $1.5 \mathrm{~km}$ wide. It includes beaches with rocky outcrops, cliffs, capes, and islands, with a great variety of seabirds and marine mammals. The climate of the latter two areas is arid, with rainfall and snowfall ranging between 110 and $150 \mathrm{~mm}$, mostly during winter (Oliva et al. 2001, González and Rial 2004). The climate is cold and windy, with mean temperatures of $8-10^{\circ} \mathrm{C}$. Most of both localities are covered by colapiche (Nassauvia glomerulosa), a small creeping shrub, and broom sedges of the genera Stipa, Festuca, Carex, and Poa. The mata negra (Junellia tridens), a low shrub, also is common in the steppes (Oliva et al. 2001). Vegetation in ravines is dominated by taller shrubs and low trees: mata amarilla (Anartrophyllum rigidum), molle (Schinus polygamus), and calafate (Berberis heterophylla). 
The single collection site in the province of Neuquén, Junín de los Andes (39 $\left.30^{\prime} \mathrm{S}, 70^{\circ} 30^{\prime} \mathrm{W}\right)$ consists of plains (elevation $800-900 \mathrm{~m}$ asl) dissected by steep rugged valleys and large rivers (lowland piedmont) and highland piedmont. The vegetation is a mixed steppe of grass and shrubs. Dominant grass species are Mullinum spinosum, Senecio spp., Stipa spp., and Poa spp., and common shrubs are Chacaya trinervis, Berberis darwinii, and Schinus molle. In the valleys are humid areas with dense herbaceous vegetation where dominant species include Cortaderia araucana, Juncus sp., and Carex sp. The climate is dry and cold with frequent snowfall in winter, and annual rainfall of 300$700 \mathrm{~mm}$. Mean annual maximum and minimum temperatures are $17.4^{\circ} \mathrm{C}$ and $2.5^{\circ} \mathrm{C}$, respectively.

Kestrel Diet. We collected pellets and prey remains from nests and nearby perches of breeding pairs during the austral breeding season: Río Chico, December 1998, one breeding pair; Monumento Natural Bosques Petrificados, September-October, 2003-2004, three breeding pairs; Ría Deseado, December 1999 and 2001, two breeding pairs; and Junín de los Andes November-December 1992, three breeding pairs. Collected material was hydrated and broken apart by hand, and prey items were identified using reference collections of the Centro de Investigaciones de Puerto Deseado (CIPD) and keys (Chehébar and Martín 1989, Pearson 1995). We identified small mammals (all were rodents) to species on the basis of skulls, dentaries, hair, and claws. We identified birds and reptiles from skull and mandible remains and feathers. We identified arthropods to the lowest taxonomic level possible using elytra, heads, mandibles, and any other identifiable parts.

We estimated the biomass of rodent and avian prey items from the literature and our unpublished records. Following Vargas et al. (2007), we assigned a biomass of $1 \mathrm{~g}$ to each invertebrate prey item. We calculated the biomass contribution of each prey type as a percent of the total biomass of all prey consumed.

To compare the diets among the study sites, we followed the methodology of Colwell and Futuyma (1971) by first calculating for each site Levins's index of food niche breadth:

$$
\mathrm{B}=1 / \sum \mathrm{p}_{\mathrm{i}}^{2},
$$

where $p_{i}$ was the relative proportion (based on frequency) of prey type $\mathrm{i}$ in the diet. This value was then used to calculate a standardized food niche breadth:

$$
\mathrm{B}_{\mathrm{sta}}=\left(\mathrm{B}-\mathrm{B}_{\min }\right) /\left(\mathrm{B}_{\max }-\mathrm{B}_{\min }\right),
$$

where $B_{\min }$ is the minimum niche breadth possible (a diet restricted to a single prey type) and $B_{\max }$ is the maximum possible niche breadth (all prey types, represented with equal frequency). This index ranged from 0 to 1.

We used $G$-tests to evaluate differences in the frequency distribution of prey categories (rodents, birds, reptiles, arthropods) among study sites, and a Kruskal-Wallis test to evaluate biomass differences among sites in Santa Cruz province. We considered probabilities $<0.05$ to be significant (Zar 1996).

\section{Results AND Discussion}

We collected and analyzed 272 pellets and seven prey remains that rendered a total of 1169 prey items comprising 38 different types (taxa) of prey (Table 1, 2). Diets differed significantly among study sites with respect to frequency, ( $G=75.2$, df $=6, P<0.01$ ). Pairwise comparisons revealed differences between Ría Deseado and Río Chico $(G=27.0, \mathrm{df}=3, P<0.01)$, Bosques Petrificados and Río Chico $(G=63.8$; df $=3 ; P<0.01)$, and Ría Deseado and Bosques Petrificados $(G=19.0$; df $=3 ; P<0.001)$. Kestrels consumed mostly invertebrates, but the types of arthropod prey consumed differed among sites (Table 1). In Ría Deseado, scorpions (Bothriuridae, 34.3\%) were the most frequently consumed prey, followed by beetles (Coleoptera, $31.8 \%$ ). Ants (Formicidae, $40.9 \%$ ) were the most frequently consumed invertebrates at Bosques Petrificados, whereas at Río Chico grasshoppers (Acrididae $22.4 \%$ ) and weevils (Curculionidae $12.1 \%$ ) predominated. At Junín de los Andes, kestrels preyed mostly on reptiles $(44.5 \%)$, followed by rodents $(35.4 \%)$, insects $(14.1 \%)$, and birds (6.0\%; Table 1). Bird species consumed included Black-chinned Siskin (Carduelis barbata), Rufous-backed Negrito (Lessonia rufa), Austral Thrush (Turdus falcklandii), and Sierra-Finch (Phrygilus sp.). However, as a caveat, we note that the number of pairs/nests at each site was small; thus, any differences among sites may actually reflect differences in local prey availability at nest sites or individual prey preferences.

With respect to biomass, there were no significant differences in diet among study sites $(H=0.7$; df $=2 ; P=$ $0.69)$ and vertebrates contributed most. Rodents consumed by kestrels were mostly sigmodontine mice, including grass mice (Abrothrix sp.) and gerbil mice (Eligmodontia sp.), considered dominant in the diverse habitats of Patagonia steppe (Cueto et al. 2008, D. Procopio unpubl. data). Predation on birds and reptiles was similar at Bosque Petrificados and Rio Chico, where kestrels consumed Least Seedsnipe (Thinocorus rumicivorus), an abundant bird in Santa Cruz province (Travaini et al. 2007). Among reptiles, Liolaemus lizards, a group widely distributed in Patagonia (Scolaro 2005), were important in the diet of kestrels at Río Chico and Bosques Petrificados.

Kestrels in Argentine Patagonia preyed most frequently on arthropods during the breeding season. This result was similar to previous reports from semiarid forest in central Argentina (Sarasola et al. 2003). Many studies throughout the species' range have characterized the American Kestrel as primarily insectivorous (e.g., Mella 2002, Smallwood and Bird 2002, Figueroa Rojas and Corales Stappung 2004, Cabral et al. 2006, Zillio 2006). However, as our results demonstrate, in some locations, vertebrates may contribute more to the diet than insects, based on biomass. 
Table 1. The diet of American Kestrels at four study sites in Argentine Patagonia during the breeding season, SeptemberDecember, 1998-2004, based on the analysis of pellets and prey remains. $N=$ number of individual prey items in sample. Estimated body mass $(\mathrm{g})$ of vertebrate prey species is in parentheses. See methods for food niche breadth.

\begin{tabular}{|c|c|c|c|c|c|c|c|c|c|c|c|c|}
\hline \multirow[b]{2}{*}{ Prey Species } & \multicolumn{3}{|c|}{ RÍA DESEADO } & \multicolumn{3}{|c|}{$\begin{array}{c}\text { BosQues } \\
\text { PETRIFICADOS }\end{array}$} & \multicolumn{3}{|c|}{ Río CHico } & \multicolumn{3}{|c|}{ JuNÍN DE LOS ANDES } \\
\hline & $N$ & $\begin{array}{c}\text { FREQUEN- } \\
\text { CY }(\%)\end{array}$ & $\begin{array}{c}\text { BIO- } \\
\text { MASS } \\
(\%)\end{array}$ & $N$ & $\begin{array}{c}\text { FREQUEN- } \\
\text { CY }(\%)\end{array}$ & $\begin{array}{c}\text { BIO- } \\
\text { MASS } \\
(\%)\end{array}$ & $N$ & $\begin{array}{c}\text { FREQUEN- } \\
\text { CY }(\%)\end{array}$ & $\begin{array}{c}\text { BIO- } \\
\text { MASS } \\
(\%)\end{array}$ & $N$ & $\begin{array}{c}\text { FREQUEN- } \\
\text { CY }(\%)\end{array}$ & $\begin{array}{c}\text { BIO- } \\
\text { MASS } \\
(\%)\end{array}$ \\
\hline \multicolumn{13}{|l|}{ Rodents } \\
\hline Abrothrix sp. (19.5) & 8 & 3.3 & 7.4 & 7 & 1.6 & 3.9 & 37 & 11.2 & 15.8 & - & - & - \\
\hline Eligmodontia sp. (19.1) & 16 & 6.6 & 14.6 & 12 & 2.8 & 6.6 & 34 & 10.3 & 14.2 & - & - & - \\
\hline Graomys griseoflavus (45.4) & - & - & - & 1 & 0.2 & 1.3 & 1 & 0.3 & 1.0 & - & - & - \\
\hline Microcavia australis (286.1) & 1 & 0.4 & 13.7 & 3 & 0.7 & 24.8 & 3 & 0.9 & 18.9 & - & - & - \\
\hline Ctenomys sp. (111.3) & 1 & 0.4 & 5.3 & 2 & 0.5 & 6.4 & 1 & 0.3 & 2.4 & - & - & - \\
\hline Euneomys sp. (84.7) & - & - & - & 1 & 0.2 & 2.4 & 4 & 1.2 & 7.4 & - & - & - \\
\hline Reithrodon auritus (61.8) & - & - & - & - & - & - & 1 & 0.3 & 1.4 & - & - & - \\
\hline Cricetidae (45.8) & 13 & 5.4 & 28.5 & 3 & 0.7 & 4.0 & 5 & 1.5 & 5.0 & 58 & 35.4 & 61.5 \\
\hline \multicolumn{13}{|l|}{ Birds } \\
\hline Thinocorus rumicivorus (54.3) & - & - & - & 1 & 0.2 & 1.6 & - & - & - & - & - & - \\
\hline Lessonia rufa $(13.5)$ & - & - & - & - & - & - & - & - & - & 2 & 1.2 & 0.6 \\
\hline Turdus falcklandii (97.4) & - & - & - & - & - & - & - & - & - & 1 & 0.6 & 2.3 \\
\hline Carduelius barbata (14.7) & - & - & - & - & - & - & - & - & - & 2 & 1.2 & 0.7 \\
\hline Phrygilus sp. (42.7) & - & - & - & - & - & - & - & - & - & 1 & 0.6 & 1.0 \\
\hline Passeriformes (39.0) & 4 & 1.7 & 7.6 & 13 & 3.0 & 15.0 & 15 & 4.5 & 13.2 & 4 & 2.4 & 3.7 \\
\hline Furnariidae (54.0) & - & - & - & 1 & 0.2 & 1.6 & - & - & - & - & - & - \\
\hline \multicolumn{13}{|l|}{ Reptiles } \\
\hline Diplolaemus bibronii (21.6) & - & - & - & - & - & - & 1 & 0.3 & 0.5 & - & - & - \\
\hline Diplolaemus sp. (25.4) & 1 & 0.4 & 1.2 & 1 & 0.2 & 0.7 & 1 & 0.3 & 0.6 & - & - & - \\
\hline Liolaemus fitzingeri (28.5) & - & - & - & 1 & 0.2 & 0.8 & - & - & - & - & - & - \\
\hline Liolaemus sp. (14.9) & 2 & 0.8 & 1.4 & 34 & 7.9 & 14.6 & 19 & 5.8 & 6.2 & - & - & - \\
\hline Leiosauridae (27.3) & 3 & 1.2 & 3.9 & 3 & 0.7 & 2.4 & - & - & - & - & - & - \\
\hline Unidentified (17.6) & 9 & 3.7 & 7.6 & 8 & 1.8 & 4.1 & 24 & 7.3 & 9.3 & 73 & 44.5 & 29.8 \\
\hline \multicolumn{13}{|l|}{ Insects } \\
\hline Odonata & 5 & 2.1 & 0.2 & - & - & - & 1 & 0.3 & $<0.1$ & - & - & - \\
\hline Orthoptera & - & - & - & & & & & & & & & \\
\hline Acrididae & 9 & 3.7 & 0.4 & 1 & 0.2 & $<0.1$ & 74 & 22.4 & 1.6 & - & - & - \\
\hline Homoptera & - & - & - & - & - & - & - & - & - & - & - & - \\
\hline Cicadidae & 3 & 1.2 & 0.1 & - & - & - & - & - & - & - & - & - \\
\hline Coleoptera & 27 & 11.2 & 1.3 & 79 & 18.2 & 2.3 & 33 & 10.0 & 0.7 & 16 & 9.8 & 0.4 \\
\hline Scarabaeidae & - & - & - & 1 & 0.2 & 0.0 & - & - & - & 7 & 4.3 & 0.2 \\
\hline Carabidae & 1 & 0.4 & $<0.1$ & 4 & 0.9 & 0.1 & 2 & 0.6 & $<0.1$ & - & - & - \\
\hline Curculionidae & 23 & 9.5 & 1.1 & 70 & 16.2 & 2.0 & 40 & 12.1 & 0.9 & - & - & - \\
\hline Tenebrionidae & 26 & 10.7 & 1.2 & 5 & 1.2 & 0.1 & 7 & 2.1 & 0.2 & - & - & - \\
\hline Epidonota sp. & - & - & - & 1 & 0.2 & $<0.1$ & - & - & - & - & - & - \\
\hline Diptera & 3 & 1.2 & 0.1 & 1 & 0.2 & $<0.1$ & 6 & 1.8 & 0.1 & - & - & - \\
\hline Hymenoptera & - & - & - & - & - & - & 2 & 0.6 & $<0.1$ & - & - & - \\
\hline Formicidae & 3 & 1.2 & 0.1 & 177 & 40.9 & 5.1 & 18 & 5.5 & 0.4 & - & - & - \\
\hline Unidentified & - & - & - & 2 & 0.5 & $<0.1$ & 1 & 0.3 & $<0.1$ & - & - & - \\
\hline \multicolumn{13}{|l|}{ Arachnids } \\
\hline Aranae & 1 & 0.4 & $<0.1$ & 1 & 0.2 & $<0.1$ & - & - & - & - & - & - \\
\hline Bothriuridae & 83 & 34.3 & 4.0 & - & - & - & - & - & - & - & - & - \\
\hline
\end{tabular}


Table 2. Sample sizes and food niche breadth of American Kestrels at four study sites in Argentine Patagonia during the breeding season, September-December, 1998-2004.

\begin{tabular}{lcccc}
\hline \multirow{2}{*}{$\begin{array}{c}\text { Collected or } \\
\text { Calculated Data }\end{array}$} & Ría Deseado & BosQues Petrificados & Río Chico & Junín DE LOS ANDES \\
\cline { 2 - 5 } & 242 & 433 & 330 & 164 \\
Number of prey items & 50 & 56 & 88 & 78 \\
Number of pellets & - & 7 & - & - \\
Number of prey remains & 0.3 & 0.1 & 0.4 & 0.2 \\
Food niche breadth & &
\end{tabular}

\section{DIETA DE FALCO SPARVERIUS EN LA PATAGONIA ARGENTINA}

REsumen.-Presentamos el primer análisis cuantitativo de la dieta de Falco sparverius en el sur de Argentina. Identificamos 1169 ítems de presas en un total de 272 egagrópilas y siete restos de presas de cuatro sitios de estudio en la Patagonia. En esta área, F. sparverius se alimentó principalmente de escorpiones (Bothruridae), escarabajos (Coleoptera), hormigas (Formicidae), saltamontes (Acrididae), gorgojos (Curculionidae) y roedores (Rodentia). La dieta difirió significativamente entre los sitios de estudio en términos de la frecuencia de varios ítems entre las presas, pero no en términos de la biomasa. De acuerdo a la frecuencia, los insectos conformaron la mayor parte de la dieta en la mayoría de los sitios, pero los vertebrados contribuyeron más en términos de biomasa.

[Traducción del equipo editorial]

\section{ACKNOWLEDGMENTS}

We thank Carlos Zoratti, Gustavo Soria, Fernando Escobar, Gabriela Aguilera, Pablo Collavino, Emilio Daher, Martín Yaya, and Mara Bronfman for their help during fieldwork, and the Administración de Parques Nacionales for authorizing us to work inside the protected area. We also thank Jay Carlisle for kindly improving the English and for helpful comments that greatly improved this paper. Funds were provided by the Universidad Nacional de la Patagonia Austral, project P.I 29/P081/2; the Agencia Nacional de Promoción Científica y Tecnológica, Project BID 1728/OC-AR PICTO Nr E-30723, and the BBVA Foundation through a grant under the Conservation Biology Programme. Miguel Angel Santillán was supported by an Inter-U fellowship. We thank Alejandro Baladrón, Sole Liébana, Annick Morgenthaler, and Fer Garcia for comments and suggestions on an earlier version of the manuscript. We also thank John A. Smallwood, Cheryl R. Dykstra and three anonymous referees for providing comments that greatly improved this manuscript.

\section{LITERATURE CITED}

Ares, J., A.M. Beeskow, C.M. Rostagno, M.P. Irisarri, J. Anchorena, G.E. Defosse, and C.A. Meroni. 1990. Structural and dynamic characteristics of overgrazed lands of northern Patagonia, Argentina. Pages 149175 in A. Bremeyer [ED.], Managed grasslands: regional studies. Elsevier Science, Amsterdam, Netherlands.
Bellati, J. 2000. Comportamiento y abundancia relativa de rapaces de la patagonia extraandina Argentina. Ornitol. Neotrop. 11:207-222.

Beltzer, A.H. 1990. Biología alimentaria del halconcito común Falco sparverius en el valle aluvial del río Paraná Medio, Argentina. Hornero 13:133-136.

Bertiller, M.B. AND A. Bisigato. 1998. Vegetation dynamics under grazing disturbance: the state-and-transition model for the Patagonia steppes. Ecol. Austral 8:191199.

Bó, M.S., A.V. BALAdRón, AND L.M. Biondi. 2007. Ecología trofica de Falconiformes y Strigiformes: tiempo de síntesis. Hornero 22:97-115.

Cabral, J.D.C., M.A.M. Granzinolli, and J.C. MottaJunior. 2006. [Diet of the American Kestrel, Falco sparverius (Aves: Falconiformes) in the Itirapina Ecological Station, São Paulo]. Rev. Bras. Ornitol. 14:393-399 (In Portuguese with English summary.)

Chehébar, C. and S. Martín. 1989. Guía para el reconocimiento microscópico de los pelos de los mamíferos de la Patagonia. Doñana Acta Vert. 16:247-293.

Colwell, R.K. AND D.J. Futuyma. 1971. On the measurements of niche breadth and overlap. Ecology 52:567576.

Cueto, G.R., P. Teta, And P. De Carli. 2008. Rodents from southern Patagonian semi-arid steppes (Santa Cruz Province, Argentina). J. Arid Environ. 72:56-61.

DE LuccA, E.R. 1992a. Métodos y éxito de caza de una hembra de Halconcito Colorado (Falco sparverius) en la Patagonia Argentina. Nuestras Aves 26:25-26.

. 1992b. Nidificación del Halconcito Colorado (Falco sparverius) en nidos de Cotorra (Myopsitta monachus). Hornero 13:238-240.

- 1993. Un caso de poligamia en el halconcito Colorado (Falco sparverius). Hornero 13:299-302.

— AND M.D. SAGGESE. 1993. Nidificación del Halconcito Colorado (Falco sparverius) en la Patagonia. Hornero 13:302-305.

Del Hoyo, J., A. Elliott, And J. SARgatal. 1994. Handbook of the birds of the world. Vol. II. New World vultures to guineafowl. Lynx Edicions, Barcelona, Spain.

Donázar, J.A., O. Ceballos, A. Travaini, and F. Hiraldo. 1993. Roadside raptor surveys in the Argentinean Patagonia. J. Raptor Res. 27:106-110. 
Ferguson-Lees, J. AND D.A. Christie. 2001. Raptors of the world. Christopher Helm, London, U.K.

Figueroa Rojas, R.A. And E.S. Corales Stappung. 2004. Summer diet comparison between the American Kestrel (Falco sparverius) and Aplomado Falcon (Falco femoralis) in an agricultural area of Araucania, southern Chile. Hornero 19:53-60.

GONZÁLEZ, L. AND P. RIAL. 2004. Guía geográfica interactiva de Santa Cruz. Estación Experimental Agropecuaria Santa Cruz. Convenio INTA-Santa Cruz-UNPA, Santa Cruz, Argentina.

Greer, J.K. AND D.S. Bullock. 1966. Notes on stomach contents and weights of some Chilean birds of prey. Auk 83:308-309.

Mazzoni, E. And M. VÁzQuez. 2004. Ecosistemas de Mallines y paisajes de la Patagonia Austral (Provincia de Santa Cruz). Ediciones INTA, Buenos Aires, Argentina.

Mella, J.E. 2002. Dieta del cernícalo (Falco sparverius) y del tucúquere (Bubo magellanicus) en un ambiente cordillerano de Chile central. Bol. Chil. Ornitol. 9:3437 .

NARosky, T. AND D. Yzurieta. 2003. Guía para la identificación de las aves de Argentina y Uruguay. Asociación Ornitológica del Plata, Vazquez Mazzini Editores, Buenos Aires, Argentina.

Oliva, G., L. Gonzáles, P. Rial, and E. Livraghi. 2001. Áreas ecológicas de Santa Cruz y Tierra del Fuego. Pages 41-82 in P. Borrelli and G. Oliva [EDs.], Ganadería ovina sustentable en la Patagonia Austral. Tecnología de manejo extensivo. Convenio INTA-UNPACAP, Río Gallegos, Santa Cruz, Argentina.

PEARson, O.P. 1995. Annotated keys identifying small mammals living near Lanin National Park or Nahuel Huapi National Park, southern Argentina. Mastozool. Neotrop. 2:99-148.

Sarasola, J.H., M.A. Santillán, and M.A. Galmes. 2003. Food habits and foraging ecology of American Kestrel in the semiarid forest of central Argentina. J. Raptor Res. 37:236-243.

ScOlARo, A. 2005. Reptiles patagónicos sur: guía de campo. Ediciones Universidad de la Patagonia San Juan Bosco, Trelew, Chubut, Argentina.
SimonetTI, J.A., H. NuÑEZ, AND J.L. YAÑEZ. 1982. Falco sparverius L.: rapaz generalista en Chile Central. Biol. Mus. Hist. Nat. Chile 39:119-124.

Smallwood, J.A. And D.M. Bird. 2002. American Kestrel (Falco sparverius). In A. Poole and F. Gill [EDs.], The birds of North America, No. 602. The Academy of Natural Sciences, Philadelphia, PA and The American Ornithologists' Union, Washington, DC U.S.A.

Soriano, A. 1983. Deserts and semi-deserts of Patagonia. Pages 423-459 in N.E. West [ED.], Temperate deserts and semi-deserts. Elsevier, Amsterdam, Netherlands.

Travaini, A., J. Bustamante, J.J. Negro, and R.D. QuinTANA. 2004. ¿Puntos fijos o recorridos lineales para el censo de aves de la estepa patagónica? Ornitol. Neotrop. $15: 513-525$.

- - J.J.A. Rodríguez, S. Zapata, D. Procopio, J. Pedrana, and R. Martínez-Peck. 2007. An integrated framework to map animal distribution in large and remote regions. Divers. Distrib. 13:289-298.

, A. Rodriguez, O. Ceballos, J.A. Donázar, and F. HiRALDO. 1995. Roadside raptor surveys in central Argentina. Hornero 14:64-66.

TREJO, A. AND V. OJEDA. 2002. Identificación de egagrópilas de aves rapaces en ambientes boscosos y ecotonales del noroeste de la Patagonia Argentina. Ornitol. Neotrop. 13:313-317.

VArgas, R.J., M.S. Bó, And M. Favero. 2007. Diet of the Southern Caracara (Caracara plancus) in Mar Chiquita Reserve, southern Argentina. J. Raptor Res. 41:113-121.

Woons, R.W. 1988. Guide to birds of the Falkland Islands. Anthony Nelson, Ltd., Shropshire, U.K.

YAÑEZ, J.L., H. NuÑEZ, R.P. SChlATER, AND F. JAKSIC. 1980. Diet and weight of American Kestrel in central Chile. Auk 97:629-631.

ZAR, J.H. 1996. Biostatistical analysis, Third Ed. Prentice Hall, Princeton, NJ U.S.A.

Zillio, F. 2006. Dieta de Falco sparverius (Aves: Falconidae) e Athene cuniculara (Aves: Strigidae) em UMA regiao de dunas no sul do Brasil. Rev. Bras. Ornitol. 14:379-392. (In Portuguese with English summary.)

Received 16 September 2008; accepted 9 July 2009 Associate Editor: John A. Smallwood 